\title{
(QUALITATIV RESEARCH) PENGALAMAN PEMBELAJARAN LABORATORIUM KEPERAWATAN JIWA METODE ROLE PLAY PADA MAHASISWA DIPLOMA III KEPERAWATAN STIKES PAMENANG
}

\section{(QUALITATIV RESEARCH) LEARNING EXPERIENCE IN MENTAL NURSING LABORATORY WITH THE ROLE PLAY METHOD IN DIPLOMA III NURSING NURSING STIKES PAMENANG}

\author{
Bambang Wiseno ${ }^{1 *}$ \\ ${ }^{1}$ STIKes Pamenang, \\ *Korespondensi Penulis : bambangwiseno0601@gmail.com, bambangwiseno72@yahoo..com
}

\begin{abstract}
Abstrak
Mempelajari ilmu asuhan keperawatan harus dilakukan secara menyeluruh, yaitu; bio, psiko, sosio, spiritual dan budaya sehingga didapatkan hasil yang optimal. Banyak model dan metode yang digunakan untuk proses pembalajaran. Metode role play dalam pembelajaran laboratorium mata kuliah asuhan keperawatan jiwa Diploma III dilakukan untuk mengaplikasikan teori keperawatan jiwa yang lebih membutuhkan kemampuan komunikasi terapeutik sebagai perawat pelaksana. Mahasiswa ketika praktik bermain peran pada pembelajaran laboratorium asuhan mempunyai berbagai pengalaman yang bermakna dan permasalahan yang tidak didapatkan ketika praktik laboratorium mata kuliah lain. Tujuan dari penelitian ini adalah untuk menemukan makna dari pengalaman mereka ketika selesai mengikuti kegiatan. Penelitian kualitatif dengan pendekatan fenomenology diskriptive dilakukan wawancara secara mendalam (indepth interview) dengan pertanyaan semistruktur terhadap enam mahasiswa secara purposive sampling setelah pembelajaran roleplay pada bulan Juni 2019 di laboratrium kampus. Interpretative Phenomenology Analysis (IPA) digunakan untuk menganalisa data dan ditemukan 7 tema, yaitu; merasa perlu tambahan praktik komunikasi terapeutik, merasa susah mempelajari keperawatan jiwa, tidak yakin akan kemampuan, merasakan seperti berhadapan langsung dengan klien, merasakan takut bila berhadapan langsung dengan klien jiwa, tidak bisa konsentrasi dalam proses role play dan merasa perlu untuk sering melakukan role play. Dari semua tema yang dihasilkan dapat disimpulkan bahwa mahasiswa ada yang merasa kesulitan mempelajari keperawatan jiwa karena persepsi yang salah tentang keperawatan jiwa sehingga merasa perlu meningkatkan pemaham teoritis materi dan sering melakukan latihan bermain peran.
\end{abstract}

Kata Kunci: Praktik Klinik, Diskriptif, Fenomenology, Keperawatan Jiwa, Komunikasi Terapeutik.

\begin{abstract}
Studying nursing care must be done thoroughly, that is; bio, psycho, socio, spiritual and culture so that optimal results are obtained. Many models and methods are used for the learning process. The role play method in learning laboratory nursing Diploma III mental nursing care is carried out to apply mental nursing theory that requires therapeutic communication skills as a practical nurse. Students when practicing role playing in mental health laboratory have a variety of meaningful experiences and problems that are not obtained when practicing laboratory in other subjects. The purpose of this research is to find the meaning of their experience when they finish participating in the activity. Qualitative research with a descriptive phenomenological approach was carried out in-depth interviews (in-depth interviews) with semi structured questions to six students by purposive sampling after role play learning in June 2019 at the campus laboratory. Interpretative Phenomenology Analysis (IPA) was used to analyze data and found 7 themes, namely; feel the need for additional therapeutic communication practices, find it difficult to study mental nursing, are unsure of ability, feel like dealing directly with clients, feel afraid when dealing directly with mental clients, cannot concentrate on the role play process and feel the need to frequently do role play. From all the themes produced it can be concluded that there are students who find it difficult
\end{abstract}


to study mental nursing because of wrong perceptions about mental nursing so they feel the need to improve theoretical understanding of the material and often do role playing exercises.

Keywords: Clinical Practice, Descriptive, Phenomenology, Psychiatric Nursing, Therapeutic Communication.

\section{Pendahuluan}

Pembelajaran adalah suatu proses atau suatu perbuatan untuk menjadikan orang belajar. Belajar untuk mendapatkan sesuatu yang sebelumnya tidak diketahui menjadi tahu. Dalam pembelajaran di bidang kesehatan khususnya pendidikan keperawatan, pengetahuan secara holistik (bio, psiko, sosio, spiritual dan budaya) harus dipunyai dan diberikan kepada mahasiswa oleh pengajar dan atau mahasiswa harus mempunyai bekal keilmuan untuk kesiapan bekerja setalah lulus nantinya. Bekal yang diharapkan dipunyai oleh mahasiswa didapatkan dalam pembelajaran teori maupun pembelajaran praktik. Pembelajaran praktik klinik dengan komunikasi terapeutik dalam keperawatan jiwa merupakan sarana untuk memberikan kesempatan mahasiswa dapat menerapkan teori ke dalam pembelajaran praktik dengan menerapkan beberapa ketrampilan intelektual. Salah satu metode pembelajaran klinik yang dapat dilakukan adalah dengan bermain peran (role play). Role play merupakan metode untuk menghadirkan peran-peran yang ada dalam dunia nyata ke dalam suatu bermain peran di dalam pembelajaran klinik yang dapat dijadikan sebagai bahan refleksi sebagai calon perawat.

Pada pendidikan vokasi keperawatan (Diploma III), lulusan diharapkan siap untuk bekerja sebagai perawat pelaksana yang mempunyai tanggung jawab besar untuk mampu berinteraksi secara profesional dalam perannya sebagai pemberi asuhan keperawatan (care giver). Kemampuan interaksi dengan klien secara profesional harus didukung oleh kemampuan komunikasi terapeutik untuk memenuhi kebutuhan psikis klien yang terganggu ${ }^{(9)}$.

Pembelajaran praktik dimaksudkan untuk menggambarkan suatu bentuk belajar professional yang menyokong terjadinya belajar yang berfokus pada pasien dan situasi yang nyata (interaksi antara pengajar, peserta didik, dan pasien) ${ }^{(7)}$. Role play pada hakikatnya untuk menghasilkan perubahan tingkah laku sebagai hasil belajar, dalam pengertian yang lebih luas mencakup perubahan bidang kognitif, afektif, dan psikomotorik. Pembelajaran untuk kebutuhan psikis khususnya asuhan keperawatan jiwa, mahasiswa dituntut mampu berkomunikasi terapeutik praktis secara efektif selain kemampuan secara teoritis ${ }^{(11)}$.

Dari paparan diatas bagaimana pengalaman mahasiswa dalam menghadapi klien setelah proses pembelajaran klinik diselesaikan. Hasil pembelajaran klinik dengan metode role play perlu mendapat perhatian untuk kesiapan mahasiswa membantu masalah psikis klien melalui keperawatan jiwa metode ini dapat dilanjutkan.

\section{Metode}

Penelitian ini menggunakan desain penelitian kualitatif pendekatan fenomenologi diskriptif. Partisipan yang terlibat dalam penelitian ini sejumlah 6 (enam) orang mahasiswa yang sesuai dengan kriteria inklusi yang ditentukan melalui purposive sampling yaitu: 1) Partisipan yang telah mendapatkan teori keperawatan jiwa, 2) Partisipan yang telah mendapatkan pembelajaran komunikasi terapeutik dan pembelajaran klinik metode role play, 3) Partisipan yang bersedia terlibat dalam penelitian, 4) Partisipan bersedia diwawancarai dan direkam selama penelitian dan memberikan persetujuan publikasi hasil penelitian. Penelitian ini hanya dilakukan pada partisipan yang telah selesai mengikuti pembelajaran laboratorium dengan metode role play.

Data dikumpulkan setelah partisipan selesai melakukan role play, pertanyaan semiterstruktur digunakan sebagai panduan untuk wawancara secara mendalam (indepth inteview) tentang pengalaman, pemahaman, perasaan serta harapan partisipan untuk kesiapan menghadapi klien setelah lulus pendidikan. Selama wawancara peneliti juga menggunakan catatan lapangan (field note). Setelah data tercukupi selanjutnya peneliti melakukan analisa data menggunakan panduan Interpretive Phenomenological Analysis (IPA) ${ }^{(1)}$ dengan alur sebagai berikut; read - re read, exploring semantic content, 
developing emergent themes, search connection across themes, bracket previous themes dan keep open minded to next case, looking for pattern across case dan taking interpretations.

\section{Hasil}

Partisipan sebanyak 6 mahasiswa dengan karakteristik sama yaitu yang telah selesai mengikuti pembelajaran teori keperawatan jiwa. Partisipan telah mengikuti pembelajaran teori komunikasi terapeutik dan menyelesaikan teori pembelajaran praktik klinik laboratorium dengan metode role play.

Hasil penelitian yang didapatkan mengacu pada tujuan penelitian ditemukan 7 (tujuh) tema yaitu; merasa perlu tambahan praktik komunikasi terapeutik, merasa susah mempelajari keperawatan jiwa, tidak yakin akan kemampuan, merasakan seperti berhadapan langsung dengan klien, merasakan takut bila berhadapan langsung dengan klien jiwa, tidak bisa konsentrasi dalam proses role play dan merasa perlu untuk sering melakukan role play.

Berikut dijelaskan penganalisaan data dari setiap tema yang ditemukan beserta penjelasan dari uraian masing-masing tema dan kategori dengan beberapa kutipan wawancara dari beberapa partisipan.

\section{1) Merasa perlu tambahan praktik komunikasi terapeutik}

Partisipan mengungkapkan bahwa dirinya "Merasa kurang dalam komunikasi terapeutik" maksud dari tema ini adalah partisipan merasa perlu lebih sering ada pembelajaran praktik komunikasi, seperti berikut:

Perasaan belum terbiasa dalam komunikasi terapeutik dengan klien jiwa, dimana partisipan mengatakan belum pernah melakukan komuniksi terapeutik dengan klien jiwa walaupun dalam praktik laboratorium. Selama ini partisipan hanya berlatih komunikasi teraputik dengan klien gangguan fisik. Kutipan dari partisipan sebagai berikut:

... teorinya sudah sih, seperti fase dalam interaksi, tapi kalau disuruh anamnese ODGJ (Orang Dengan Gangguan Jiwa) yaa ngomongnya itu gimana .. (P2)

Kalau role play memasang infus pernah pak, tapi kalau seperti ini,.. belum pernah. Jadi gak tahu caranya ngomong yang enak., kan pasiennya $O D G J$... (P5)
Partisipan baru pertama kali mengikuti pembelajaran role play keperawatan jiwa, dua partisipan merasa bingung memulai komunikasi dengan klien di role play. Kutipan wawancaran dari dua partisipan tersebut sebagai berikut:

... bingung pak, karena belum pernah role play jiwa ... kalau di mata kuliah komunikasi terapeutik sudah dengan kasus KMB (Keperawatan Medikal Bedah) (P2).

Kalau role play memasang infus pernah pak, tapi kalau seperti ini,.. belum pernah. Jadi gak tahu caranya ngomong yang enak., kan pasiennya ODGJ ... (P5)

... pura-pura jadi gila pak susah, karena belum pernah seperti ini ..... (P3)

\section{2) Merasa susah mempelajari keperawatan jiwa}

Partisipan menyampaikan bahwa dirinya "tidak menyukai mata kuliah abstrak", maksud dari tema ini adalah partisipan berpikir bahwa kejiwaan tidak dapat/susah bila dipraktikkan.

Perasaan tidak suka membahas masalah yang tidak nyata, disini partisipan beranggapan bahwa kejiwaan merupakan hal yang susah untuk dipelajari karena merupakan suatu yang abstrak. Partisipan selama perkuliahan dan praktik yang pernah dijalani belum pernah membahas tentang psikis klien pada kasus fisik. Kutipan dari wawancara dengan partisipan seperti berikut:

... jiwa itu gak jelas pak, angel (susah) ..., jadi masing-masing orang mungkin salah penafsirannya ... (P1).

Menurut saya kurang penting ..., kan kalau orang-orang itu mungkin bisa bohong dan di praktik ini kan semua teman ... (P3).

Bingung pak, he he,... lhaa kemarin-kemarin praktiknya di rumah sakit " $A$ " (rumah sakit lahan praktik semester sebelummnya) belum pernah di rumah sakit jiwa.(P2).

\section{3) Tidak yakin akan kemampuan}

Partisipan mengungkapkan bahwa dirinya "Merasa dirinya tidak punya keberanian berhadapan dengan ODGJ" dimana maksud dari tema ini adalah partisipan merasa kurang percaya diri merawat klien dengan gangguan jiwa karena selama ini klien yang dihadapi masih masalah fisik klien.

Belum adanya pengalaman dalam praktik aplikasi jiwa di laboratorium maupun lapangan menyebabkan partisipan merasa 
tidak yakin dengan kemampuannya, seperti berikut:

... grogi, apakah saya nanti bisa memberikan asuhan sesuai teori ... (P4)

... belum bisa membayangkan pak ..., bagaimana nantinya orang dengan gangguan jiwa aslinya ... (P3).

\section{4) Merasa seperti berhadapan langsung dengan klien}

Di tema ini partisipan mengungkapkan bahwa dirinya "serasa berhadapan dengan klien OGDJ". Maksud dari tema ini adalah partisipan bisa membayangkan bahwa dalam pembelajaran role play itu klien yang dihadapi seperti asli mengalami gangguan jiwa.

Mendapat gambaran susahnya berhadapan dengan klien gangguan jiwa, partisipan kesulitan untuk melakukan anamnese karena jawaban dari klien "mbulet". (Mbulet adalah bahasa jawa yang berarti berbelit-belit):

... di group saya, yang menjadi klien mbulet pak ketika ditanya ..., jadi bayangin kalau besok yang dihadapi seperti itu ... (P6).

... yang jadi klien cengengesan pak,... persis seperti orang gila beneran ... (P2).

... teman saya actingnya beneran e pak kayak ODGJ beneran ... (P5)

... punya pengalaman ngobrol dengan ODGJ walaupun pura-pura ... (P4)

\section{5) Merasa takut bila berhadapan langsung dengan klien jiwa}

Di tema ini, partisipan ketakutan jika berhadapan dengan hal yang berhubungan dengan ODGJ. Ada "perasaan takut yang dirasakan partisipan", pengalaman terdahulu yang dialami partisipan mempengaruhi proses pembelajaran role play.

Stigma yang ada pada partisipan terhadap ODGJ yang masih memandang bahwa ODGJ berkaitan dengan kekerasan yang dilakukan. Kutipan dari partisipan seperti berikut:

... tetangga saya ada yang ngamuk-ngamuk pak ... jadi tadi pas role play kepikiran kalau ngamuk saya gimana gitu nantinya ke klien ... $(P 1)$.

... belum bisa membayangkan pak ..., bagaimana nantinya orang dengan gangguan jiwa aslinya ... (P3).

6) Tidak bisa konsentrasi dalam proses role play

$$
\text { Partisipan menyampaikan adanya }
$$

Maksud dari tema ini adalah adanya anggota tim role play yang kurang memperhatikan proses dan peran yang dimainkan.

Kurangnya pemahaman partisipan dalam proses pembelajaran laboratorium dengan role play berpengaruh ketika partisipan memerankan diri. Keadaan ini mempengaruhi tim lainnya. Beberapa partisipan mengatakan sebagai berikut:

... lha ... guyon (bercanda) aja pak tanyanya... saya jadi pasien yaa jadi ikutan ... (Pl)

... dia jadi pasien serius banget seperti marah marah beneran ... ditanya gak jawab terus marah-marah ... (P6)

... si A jadi pasiennya mengkhayalnya keterlaluan pak ... sampai saya bingung gimana anamnesenya. (P3)

7) Merasa perlu lebih sering melakukan role play

Beberapa partisipan menyampaikan bahwa "perlu adanya tambahan kegiatan role play". Dimaksudkan disini adalah, partisipan merasa tidak cukup hanya dengan sekali praktik.

Partisipan belum banyak mendapatakan sesuai yang diharapkan dalam pembelajaran role play. Kutipan dari partisipan mengenahi hal ini seperti berikut:

Saya sendiri merasa kurang puas, gak tahu kalau teman-teman ... belum begitu menjiwai peran jadi pasien ... (Pl)

... tapi kayaknya perlu latihan lagi ... biar semua mendapa jatah peran ... tadi saya hanya memerankan jadi perawat saja (P6)

... Senang sih pak.. tapi yaitu ... kurang persiapan ... harusnya hari ini dikasih kasus, trus besok dipraktikkan (P3).

... jam kosong mau pak begini lagi biar besok kalau praktik di RSJ tidak bingung... (P2)

\section{Interaksi antar tema}

Dari tema-tema hasil penelitian dapat dibuat skema tentang interaksi antar tema untuk ditemukan inti tema (Core Theme) perlu latihan komunikasi terapeutik dengan bermain peran (role play) lebih dari sekali. Mahasiswa merasakan bahwa belajar serta mempraktikkan jiwa adalah susah yang merupakan suatu yang abstrak yang tidak nyata. Hal abstrak yang termanifestasikan pada klien jiwa menyebabkan mahasiswa merasakan kuwatir dan ketakutan bila berhadapan dengan klien ODGJ, ini mungkin disebabkan karena kurangnya pemahaman 
mahasiswa terhadap teori keperawatan jiwa. Peran ODGJ yang dimainkan oleh mahasiswa diperankan sesuai dengan asumsi yang dipikirkan oleh mahasiswa, bahwa ODGJ tidak dapat diajak komunikasi. Namun dari beberapa mahasiswa, mereka merasa perlu untuk praktik lebih dari sekali dengan harapan bisa menangani klien di kemudian hari.

\section{Pembahasan}

\section{Merasa perlu tambahan praktik komunikasi terapeutik}

Menghadapi manusia sebagai kesatuan yang utuh (bio-psiko-sosio-sipritual) dalam asuhan keperawatan sangatlah dibutuhkan kemampuan perawat ketika berkomunikasi dengan manusia lain. Dalam pelaksanaannya dilapangan tidak hanya kemampuan komunikasi yang menjadi prioritas, namun komunikasi yang berbasis terapeutik harus dimiliki oleh perawat, sehingga komunikasi yang dilakukan dapat memberikan efek terapeutik pada klien. Kemampuan interpersonal pengajar dalam komunikasi akan membantu mahasiswa menguasai materi (4) Pembelajaran untuk dapat mendapatkan hasil yang optimal memerlukan pengulangan materi belajar $^{(5)}$.

Pembelajaran dalam meningkatkan kemampuan menggunakan bahasa yang sesuai serta berkomunikasi terapeutik pada mahasiswa memerlukan proses yang panjang (13). Hal ini untuk membiasakan diri mahasiswa menggunakan bahasa dan bentuk komunikasi yang sesuai dengan keadaan klien. Khususnya pada keperawatan jiwa yang mana klien banyak mengalami masalah dalam komunikasi, maka mahasiswa perlu membiasakan untuk melatih diri berkomunikasi terapeutik dalam pembelajaran praktik untuk persiapan menghadapi klien setelah lulus pendidikan keperawatannya.

\section{Merasa susah mempelajari keperawatan jiwa}

Persepsi merupakan batasan yang digunakan pada proses memahami dan menginterpretasikan informasi sensori, atau kemampuan intelek untuk mencarikan makna dari data yang diterima oleh berbagai indera (14). Mahasiswa merasa bahwa jiwa adalah suatu hal yang abstrak dan susah dipelajari, maka akan menghasilkan pemikiran bahwa suatu yang abstrak adalah susah. Hal ini mengakibatkan ketidakmampuan dalam fungsi-fungsi perseptual motoriknya yang menyebabkan mahasiswa mengalami kesulitan belajar termasuk dalam pembelajaran laboratorium roleplay.

\section{Tidak yakin akan kemampuan}

Mahasiswa belum pernah praktik langsung atau berhadapan dengan ODGJ di rumah sakit. Pengalaman dan pemahaman yang kurang bisa menyebabkan kurangnya rasa percaya diri ${ }^{(12)}$. Orang yang mempunyai kepercayaan diri rendah cenderung memiliki perasaan negatif terhadap dirinya, tidak punya keyakinan yang kuat atas dirinya. Orang yang punya kepercayaan diri bagus bukanlah orang yang hanya merasa mampu namun yang mengetahui bahwa dirinya mampu berdasarkan pengalaman dan perhitungannya. Orang yang tidak percaya diri memiliki konsep diri negatif, kurang percaya pada kemampuannya.

\section{Merasakan seperti berhadapan langsung dengan klien}

Perasaan positif kemampuan mahasiswa dalam teori dapat membuka diri untuk siap menerima keadaan pembelajaran. Berperan menjadi ODGJ yang sesuai dengan tanda dan gejala pada teori membuat keadaan seperti aslinya. Penguasaan bahan-bahan pelajaran dengan pengembangan imajinasi dan penghayatan mahasiswa dalam berperan mempengaruhi keberhasilan pada semua tim role play dalam memerankan perannya ${ }^{(3)}$.

\section{Merasakan takut bila berhadapan langsung dengan klien jiwa}

Kecemasan adalah suatu keadaan yang ditandai oleh rasa takut dan khawatir yang tidak didukung dengan situasi disertai dengan gejala somantik yang menandakan suatu kegiatan berlebihan dari susunan saraf autonomik, hal ini merupakan respon normal terhadap situasi yang mengancam dan dapat menjadi faktor motivasi yang positif dalam kehidupan seseorang ${ }^{(8)}$. Kecemasan pada mahasiswa ini mengakibatkan persepsi menjadi berkurang terhadap apa yang sedang dihadapi, sehingga mengurangi kemampuan mengeksplorasi diri dalam bermain peran.

Tidak bisa konsentrasi dalam proses role play

Metode pembelajaran role play merupakan pembelajaran yang didasarkan 
pada konsep pembelajaran fenomenologik yang menyadari pembelajaran sebagai proses individu yang memerlukan keterlibatan aktif peserta didik. Role play melibatkan semua tim berperan dengan benar sesuai teori di pembelajaran kelas. Tidak berperannya anggota tim menyebabkan tidak berjalannya pembelajaran role play yang menyebabkan anggota lain kurang mampu berkonsentrasi. Kurang konsentrasi menyebabkan kemampuan mengaplikasikan analisis dan sintesis pengetahuan yang diperoleh selama di kelas menjadi berkurang ketika belajar di praktik laboratorium. Apalagi kondisi ini di dukung dengan psikologis mahasiswa yang tidak sama ketika belajar juga mempengaruhi konsentrasi mahasiswa ${ }^{(6)}$.

\section{Merasa perlu untuk sering melakukan role play}

Belajar dengan bermain peran memerlukan banyak orang untuk saling mengerti dan memahami baik yang memiliki pengetahuan tinggi maupun rendah, dimana semua komponen saling tergantung. Untuk itu mengharuskan semuanya sejalan dan seirama sehingga perlu harmonisasi dari seluruh tim. Keterampilan untuk memahami orang lain tidak dapat dilakukan dengan sekali bertemu, begitu juga dalam pembelajaran yang memerlukan kemampuan untuk bekerja sama dan kegiatan terstruktur ${ }^{(2)}$ yang berulang untuk dilakukan ${ }^{(5)}$.

\section{Implikasi Dalam Keperawatan}

Hasil penelitian menunjukkan bahwa mahasiswa memerlukan latihan/praktikum laboratorium jiwa lebih dari sekali, meningkatkan kemampuan komunikasi teraputik untuk semua jenis klien, merasa senang serasa berhadapan langsung dengan klien nyata. Interpersonal skill dari masingmasing mahasiswa sangat diperlukan karena keterampilan memahami orang lain tidak dipunyai mahasiswa maka role play tidak akan berjalan dengan baik. Mahasiswa akan bisa melakukan dialog dengan baik, jika bisa memahami peran lainnya. Peneliti menyampaikan hal ini kepada semua tim pengajar keperawatan jiwa untuk menambah jumlah pertemuan dalam praktik klinik.

\section{Kesimpulan}

Berdasarkan hasil penelitian dapat disimpulkan bahwa mahasiswa dalam pembelajaran laboratorium klinik (role play) merasa perlu meningkatkan pemaham teoritis materi dan latihan bermain peran lebih dari sekali. Kemampuan komunikasi terapeutik dan kesiapan diri sangat diperlukan oleh mahasiswa sebagai calon perawat yang nantinya langsung berhadapan dengan pasien sebagai manusia yang utuh bio-psiko-sosiospiritual dan budaya. Penelitian ini memiliki keterbatasan yaitu penelitian hanya dilakukan pada mahasiswa diploma III yang mendapat pembelajaran teori keperawatan jiwa sesuai dengan kompetensi sehingga pengalaman yang didapat hanya kasus jiwa sesuai kompetensinya. Wawancara hanya menekankan pada pengalaman partisipan selama mengikuti pembelajaran klinik model role play khusus untuk keperawatan jiwa yang asuhan keperawatannya lebih menggunakan komunikasi.

\section{Saran}

Role play dalam pembelajaran klinik khususnya di keperawatan jiwa memerlukan latihan dan praktikum yang memungkinkan mahasiswa mampu menghadapi klien dengan banyak kasus jiwa. Dalam praktiknya di pembelajran laboratorium mungkin diperlukan latihan lebih dari sekali yang menjadikan mahasiswa siap bila berhadapan dengan klien secara nyata di lapangan nantinya. Pengajar khususnya yang membidangi mata kuliah yang membutuhkan kemampuan komunikasi terapeutik mahasiswa, perlu penambahan jam praktikum. Perlu penelitian lebih lanjut tentang pengalaman mahasiswa yang telah lulus terhadap kemampuan komunikasi terapeutik yang dimiliki dari pembelajaran klinik role play. Sehingga dimungkinkan ada temuan yang tepat untuk membantu mahasiswa benarbenar siap bila menghadapi klien di kasus nyata di lapangan kerjanya.

\section{Daftar Pustaka}

Linda, S. (2011). Phenomenology for Therapists. Researching the lived World. Publiser WileyBlackwell. 1st Edition, ISBN-13: 9780470666456

Mawardi, M. (2018). Merancang Model dan Media Pembelajaran. Scholaria: Jurnal Pendidikan dan Kebudayaan, 8(1), 26-40.

Melvin L. Silberman (2016). Active Learning : 101 Cara Belajar Mahasiswa Aktif. Penerjemah: Raisul Muttaqie, Bandung: Nusa Cendikia, ISBN: 978-602-7768-58-1 
Pontoh, W. P. (2013). Peranan komunikasi interpersonal guru dalam meningkatkan pengetahuan anak. Jurnal Acta Diurna,2(1).

Purwanto, (2010), Evaluasi Hasil Belajar, Yogyakarta, Pustaka Belajar.

Rahmayani, D. (2017). Faktor-faktor yang mempengaruhi konsentrasi belajar pada Mahasiswa Program Studi Ilmu Keperawatan Universitas Muhammadiyah Yogyakarta.

Rofiq, A. (2009). Metode pembelajaran klinik keperawatan. Diakses 22 Agustus 2019. URL : http//www. ahmadrofiq.com/?p=63 - 16k.

Sadock, Benjamin J. (2015) Kaplan \& Sadock buku ajar psikisyttri klinis / Nemjamkin J. Sadock, Virginia A. Sadock; alih bajasa, Profitasari, Tiara Mahatmi Nisa; edityor edisi bahasa Indonesia, Husny Muttaqim, Retna Neary Elseria Sihombing, edisi 2, Jakarta: EGC.

Setiawati, Dermawan. (2008). Proses Pembelajaran Dalam Pendidikan Kesehatan. Jakarta; Trans Info Media

Smith, J.A., Flower, P. \& Larkin, M. (2009). Interpretative Phenomenological Analysis: Theory, Method and Research. London: Sage.

Stuart. G.W. (2016). Prinsip dan Praktik Keperawatan Kesehatan Jiwa Stuart. Edisi Indonesia oleh Budi Anna Keliat dan Jesika Pasaribu. Elsevier: Singapore.

Triningtyas, D. A. (2016). Studi Kasus Tentang Rasa Percaya Diri, Faktor Penyebabnya Dan Upaya Memperbaiki Dengan Menggunakan Konseling Individual. Counsellia: Jurnal Bimbingan dan Konseling, 3(1).

Wicaksono, A., dkk. (2016). Teori Pembelajaran Bahasa: Suatu Catatan Singkat Edisi Revisi. Yogyakarta: Garudhawaca

Yusuf A, Fitryasari R, Hanik E.N. (2015) Buku Ajar Keperawatan Kesehatan Jiwa Jakarta: Salemba Medik. 